\title{
Kajian Perhitungan Beban Pencemaran Air Sungai Di Daerah Aliran Sungai (DAS) Cikapundung dari Sektor Domestik
}

\author{
Yushi Rahayu', Iwan Juwana ${ }^{2}$, Dyah Marganingrum ${ }^{3}$ \\ ${ }^{1,2}$ Jurusan Teknik Lingkungan, Fakultas Teknik Sipil dan Perencanaan,, ITENAS, Bandung \\ ${ }^{3}$ Pusat Penelitian Geoteknologi-Lembaga Ilmu Pegetahuan Indonesia \\ Email: yushirahayu@gmail.com
}

\begin{abstract}
ABSTRAK
Sungai Cikapundung merupakan anak sungai DAS Citarum Hulu yang digunakan untuk sumber air baku air minum, irigasi dan perikanan di Kota Bandung. Sungai Cikapundung yang melewati Kabupaten Bandung Barat, Kota Bandung dan Kabupaten Bandung berpotensi tercemar oleh limbah dari sektor domestik. Namun saat ini belum ada informasi mengenai beban pencemar terhadap Sungai Cikapundung dari sektor domestik. Oleh karena itu perlu dilakukan penelitian dengan tujuan untuk mengukur tingkat pencemaran di Sungai Cikapundung dengan menghitung, status mutu air, potensi beban pencemaran sektor domestik. Status mutu air ditentukan dengan menggunakan metode indeks pencemar dan potensi beban pencemaran Sungai Cikapundung dihitung menggunakan pendekatan faktor emisi limbah domestik. Berdasarkan hasil perhitungan menunjukan bahwa Sungai Cikapundung pada tahun 2016 memiliki kriteria mutu air cemar sedang pada bulan kering dan cemar ringan di bulan basah. Sungai Cikapundung telahtercemar limbah domestik berdasarkan hasil perhitungan beban pencemar mengalami kenaikan seiring dengan meningkatnya jumlah penduduk pada tahun 2021 oleh 25.383,89 Kg/ hari TSS, 17.537,96 kg/hari BOD, 18.461,01 kg/hari COD, 889,97 kg/hari $N$-Total dan 96,92 Kg/hari P-Total.
\end{abstract}

Kata kunci: Beban Pencemar, Domestik Cikapundung, Kualitas Air

\begin{abstract}
Cikapundung river is the sub river of upper Citarum River which was used by the people in Bandung city as a raw water for drinking water, irrigation and fishery. Cikapundung river that passes through many districts of Bandung have a great potential of being polluted by from domestic waste. This condition will affects the water quality of Cikapundung water. Having this condition, the urgency of conducting the research for measure the polution level at Cikapundung river was reasonable, with calculating the water quality status, the potential polutions domestic sector. Water quality status is determined by using pollution index method and potential pollution load of Cikapundung River using domestic polution emission factor approach. Result of pollutant index calculation Cikapundung River at 2016 in dry months has severe polluted water quality. Cikapundung watershed contaminated with domestic waste in the calculation of polluted pollutant potency in 2016 by 25.383,89 Kg / day TSS, 17,537.96 kg / day BOD, 18.461.01 kg / day COD, $889.97 \mathrm{~kg} /$ day $\mathrm{N}$-Total and $96.92 \mathrm{Kg} /$ day P-Total.
\end{abstract}

Keywords: Pollution Load, Cikapundung Domestic, Water. 


\section{PENDAHULUAN}

Daerah aliran sungai (DAS) Cikapundung meliputi wilayah seluas 15.386,5 hektar dengan wilayah administrasi Kabupaten Bandung Barat, Kota Bandung, dan Kabupaten Bandung. Sungai Cikapundung berhulu di Gunung Bukit Tunggul, mengalir melalui Kota dan Kabupaten Bandung lalu bermuara di Sungai Citarum. Panjang Sungai Cikapundung mencapai 28.000 meter dengan lebar sungai di hulu 22 meter dan di hilir 26 meter [1]

Penggunaan lahan seperti pertumbuhan pemukiman di DAS Cikapundung menyebabkan kurang seimbanganya antara upaya pemanfaatan DAS Cikapundung dengan upaya pelestarian DAS Cikapundung sehingga menimbulkan permasalahan lingkungan. Permasalahan yang terjadi di DAS Cikapundung pada dasarnya diakibatkan oleh pertumbuhan penduduk yang tidak terkendali yang berakibat meningkatnya beban pencemaran perairan.

Keadaan lingkungan serta ekosistem Sungai Cikapundung terutama yang melewati pemukiman padat sudah sangat mengkhawatirkan. Sungai yang dulunya menjadi sumber kehidupan bagi masyarakat lokal airnya telah berubah menjadi keruh dan bau, bantaran menjadi sempit dan banyak sampah yang terlihat. Berdasarkan uraian diatas perlu dilakukan kajian daya tampung beban pencemaran sektor domestik sebagai bahan pertimbangan dalam pengelolaan kualitas air.

Berdasarkan latar belakang permasalahan di atas, maka tujuan penelitian ini adalah (1) Menganalisis kualitas air Sungai Cikapundung ditinjau dari parameter fisika, kimia, dan biologi, (2) mengkaji potensi beban pencemaran sektor domestik di DAS Cikapundung, (3) Melakukan perhitungan potensi sebaran beban pencemar domestik di DAS Cikapundung. Manfaat dari penelitian ini diharapkan dapat digunakan untuk memperkirakan indikasi sumber pencemar sungai sektor domestik agar dapat dilakukan upaya pengendalian yang tepat sasaran.

\subsection{Layout}

\section{METODOLOGI}

Data utama yang digunakan pada kajian ini adalah data sekunder yang didapat dari berbagai instansi yang terdapat di DAS Cikapundung berupa data kualitas dan kuantitas air Sungai Cikapundung pada tahun 2014-2016 diperoleh dari Balai Besar Wilayah Sungai (BBWS) Citarum Provinsi Jawa Barat, Data jumlah penduduk DAS Cikapundung 10 tahun terakhir diperoleh dari Badan Pusat Statistik (BPS) Provinsi Jawa Barat, strategi sanitasi kota/kabupaten berupa cakupan pelayanan air limbah diperoleh dari Dinas Keseahatan Provinsi Jawa Barat. Serta data lainnya yang berkaitan dalam penelitian ini.

Tabel 1. Penilaian Status Mutu Air

\begin{tabular}{cc}
\hline Indeks & Penilaian \\
\hline $0 \leq \mathrm{PIj} \leq 1$ & Memenuhi Baku Mutu \\
$1<\mathrm{PIj} \leq 5$ & Cemar Ringan \\
$5<\mathrm{PIj} \leq 10$ & Cemar Sedang \\
$\mathrm{PIj}>10$ & Cemar Berat \\
\hline
\end{tabular}

Sumber: KepMenLH No 115 Tahun 2003

Penilaian status mutu air berdasarkan Keputusan Menteri Lingkungan Hidup No. 115 Tahun 2003 tetang Pedoman Penentuan Status Mutu Air, dimana nilai tersebut dapat digunakan untuk mengevaluasi kriteria sungai Cikapundung terhadap Peraturan Pemerintah No. 82 Tahun 2001 tentang Pengelolaan Kualitas Air dan Pengendalian Pencemaran Air Kelas I sebagai air baku. Metode penilaian status mutu air studi ini menggunkan metode indeks pencemar.

Beban pencemaran maksimum adalah beban pencemaran yang diperbolehkan di suatu sungai berdasarkan peruntukannya. Perhitungan ini dimaksudkan untuk mengetahui kondisi awal sungai tanpa adanya masukan sumber pencemar, dengan rumus perhitungan sebagai berikut: 
$\mathbf{B P M}=\mathbf{Q} \times \mathbf{C}_{\mathbf{B M}}$, dimana:

$\mathrm{BPM}=$ Beban pencemar maksimum $(\mathrm{kg} / \mathrm{hari})$

$\mathrm{Q}=$ Debit terukur $\left(\mathrm{m}^{3} /\right.$ detik)

$\mathrm{C}_{\mathrm{BM}}=$ Konsentrasi (Standar baku mutu berdasarkan Peraturan Pemerintah No. 82/2001 tentang Pengelolaan Kualitas Air dan Pengendalian Pencemaran Air Kelas I) (mg/liter)

Beban pencemaran aktual adalah beban pencemaran yang dihasilkan di suatu sungai pada saat kondisi eksisting, rumus yang digunakan dalam menghitung beban pencemaran aktual adalah:

BPA $=\mathbf{Q} \times \mathbf{C}_{\mathbf{M}}$, dimana:

$\mathrm{BPA}=$ Beban pencemar aktual $(\mathrm{kg} / \mathrm{hari})$

$\mathrm{Q}=$ Debit terukur $\left(\mathrm{m}^{3} /\right.$ detik)

$\mathrm{C}_{\mathrm{M}} \quad=$ Konsentrasi terukur (mg/liter)

Perhitungan beban pencemar proyeksi berasal dari sumber pencemar yang berasal dari sector domestik. Faktor utama menentukan potensi beban pencemar sektor domestik adalah dengan mengetahui jumlah dan pertumbuhan Untuk hal tersebut perlu dilakukan analisis untuk memperkirakan jumlah penduduk sampai tahun 2021. Adapun cara perhitungan adalah dengan menggunakan metode geometri, dengan persamaan sebagai berikut.

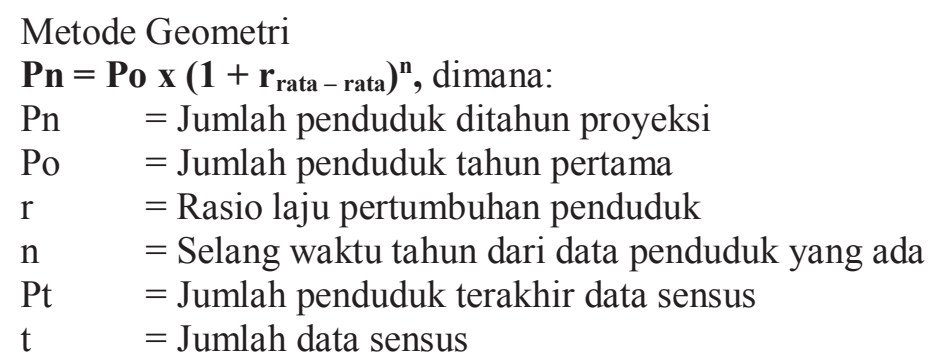

Setelah didapatkan jumlah penduduk sampai dengan tahun 2021, maka potensi beban pencemar dari sektor domestik dapat dihitung dengan persamaan sebagai berikut [2]

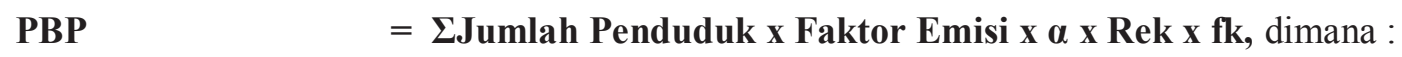

PBP $\quad=$ Potensi beban pencemar $(\mathrm{kg} / \mathrm{hari})$

¿Jumlah Penduduk = Jumlah penduduk proyeksi (Jiwa)

$\alpha$

$=$ Koefisien transfer beban, ditentukan berdasarkan jarak pemukiman ke sungai dengan kriteria (iskandar, 2010) sebagai berikut

Nilai $\alpha=1$, digunakan untuk daerah yang lokasinya berjarak antara 0 sampai 100 meter dari sungai, dengan asumsi $100 \%$ limbah domestik rumah tangga dibuang ke sungai

Nilai $\alpha=0,85$ untuk lokasi yang berjarak diantara 100-500 meter dari sungai, dengan asumsi $85 \%$ limbah domestik rumah tangga dibuang ke sungai (karena ada effisien 15\% melalui tehnologi pengolahan limbah)

Nilai $\alpha=0,3$ untuk lokasi yang berjarak lebih besar dari 500 meter dari sungai, asumin bahwa 30\% limbah domestik dibuang ke sungai (effisien $70 \%$ melalui tehnologi pengolahan limbah dan proses alami ke dalam tanah)

Pada perhitungan potensi beban pencemar DAS Cikapundung digunakan nilai $\alpha=1$, dikarenakan jumlah penduduk yang dihitung merupakan penduduk yang tidak terlayani IPAL onsite maupun offsite

Rek

$=$ rasio ekivalen kota, pola hidup mempengaruhi besaran beban pencemar yang dihasilkan pada setiap orang. Pola hidup di kota berbeda dengan pola hidup di daerah yang tingkat kehidupannya masih alami. Nilai rasio 
ekivalen untuk masing-masing kota, yaitu $\operatorname{kota}=1$, pinggiran $\operatorname{kota}=0,8125$, dan pedalaman $=0,625$.

Beberapa kecamatan di DAS Cikapundung ada yang masuk ke dalam pinggiran kota seperti Kecamatan Baleendah, Dayeuhkolot, Cimenyan, dan Lembang selain kecamatan tersebut termasuk digunakan rasio ekivalen kota.

$\mathrm{Fk}$

$=$ Faktor konversi satuan, $1 \mathrm{~kg}=1.000$ gram

Tabel 2. Nilai Faktor Emisi Domestik

\begin{tabular}{clc}
\hline No & Parameter & $\begin{array}{c}\text { Faktor Emisi } \\
\text { (g/orang/hari) }\end{array}$ \\
\hline 1. & TSS & 38 \\
2. & BOD & 40 \\
3. & COD & 55 \\
4. & Total-N & 1,95 \\
5. & Total-P & 0,21 \\
Sumber: Iskandar, 2007 &
\end{tabular}

\section{HASIL DAN PEMBAHASAN}

\subsection{Penilaian Status Mutu Air}

Di DAS Cikapundung terdapat 22 kecamatan yang berada pada daerah Kabupaten Bandung Barat, Kota Bandung dan Kabupaten Bandung. Dalam menentukan kualitas air Sungai Cikapundung, BBWS melakukan sampling pada koordinat $107^{\circ} 37^{\prime}$ ' 18,69' BT dan $6^{\circ} 56^{\prime}$ '57,19' LS yang berada di Kelurahan Pasirluyu, Kecamatan Regol, Kota Bandung. Sungai Cikapundung dimanfaatkan sebagai salah satu sumber air baku bagi kehidupan masyarakat kota Bandung, salah satu pemanfaatan Sungai Cikapundung sebagai penyedia air baku Perusahaan Daerah Air Minum (PDAM) Tirtawening Kota Bandung,

Indeks pencemar Sungai Cikapundung tahun 2014-2016 dilihat pada Tabel 3 pada tahun 2015 di bulan kering tergolong cemar berat dan cemar ringan di bulan basah tahun 2016, berdasarkan analisis indeks maksimum (IM) diketahui bahwa parameter utama yang menyebabkan menurunnya kualitas Sungai Cikapundung pada tahun 2014 sampai dengan 2016 adalah fecal coliform, keberadaan fecal coliform dalam Sungai Cikapundung. Hal ini mengindikasi bahwa Sungai Cikapundung tercemar oleh kotoran manusia yang berasal dari aktivitias mandi, cuci, kakus (MCK), penduduk, jika dilihat pada Gambar 1 mengenai peta sebaran pemukiman di DAS Cikapundung, bahwa tata guna lahan di DAS Cikapundung sebagai besar berupa kawasan pemukiman dengan kepadatan terbesar berpusat di Kota Bandung. 


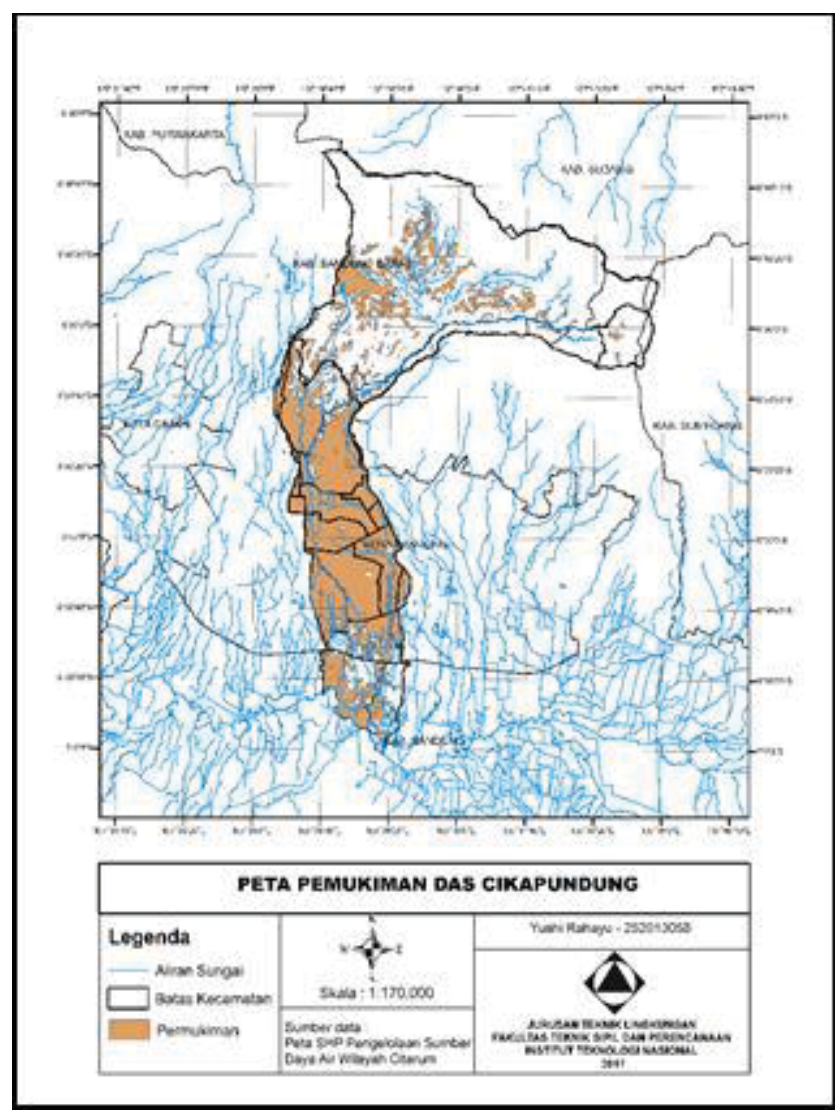

Gambar 1. Peta Sebaran Pemukiman

Banyaknya buangan organik ke dalam Sungai Cikapundung juga dapat menyebabkan penurunan kualitas air karena meningkatnya konsentrasi parameter Nitrit BOD, COD, dan DO yang terukur melebihi baku mutu pada tahun 2014-2016. Indeks pencemar DAS Cikapundung pada tahun 2014 dibulan kering lebih kecil dari bulan basah, hal ini dapat disebabkan ketika terjadi hujan, air yang mengalir pada permukaan tanah dan terakumulasi di sungai dan menyebabkan fecal coli di Sungai Cikapundung terukuran besar dan mempengaruhi mutu air.

Tahun 2015-2016 indeks pencemar bulan kering lebih besar dibandingkan pada bulan basah, nilai indeks pencemar terbesar pada bulan kering di tahun 2015, disebabkan dampak dari terjadinya kemarau panjang yang berlangsung sehingga mempengaruhi kualitas air karena berkuranganya debit yang mengalir dan terjadi penumpukan zat pencemaran sehingga menurunkan kualitas air sungai. Menurut suara pembaruan 11 juli 2015 terjadi fenomena el nino di Indonesia yang menyebabkan kemarau panjang dan mempengaruhi mutu air Sungai Cikapundung

Tabel 3 Indeks Pencemar Bulan Kering dan Bulan Basah Sungai Cikapundung

\begin{tabular}{ccccl}
\hline \multirow{2}{*}{ Tahun } & \multicolumn{2}{c}{ Bulan Kering } & \multicolumn{2}{c}{ Bulan Basah } \\
\cline { 2 - 5 } & PI & Kriteria & PI & Kriteria \\
\hline $\mathbf{2 0 1 4}$ & 3.67 & Cemar Ringan & 19.9 & Cemar Berat \\
\hline $\mathbf{2 0 1 5}$ & 23.58 & Cemar Berat & 8.75 & Cemar Sedang \\
\hline $\mathbf{2 0 1 6}$ & 5.59 & Cemar sedang & 4.54 & Cemar Ringan \\
\hline
\end{tabular}

Sumber: Hasil Perhitungan, 2018

\subsection{Perhitungan Beban Pencemar Eksisting}

Penentuan beban pencemar sungai Cikapundung ini dilakukan pada tahun 2014-2016. Parameter yang akan digunakan dalam perhitungan ini adalah parameter kunci pencemaran air, dalam penelitian Iskandar [2] adalah bahwa paramater kunci adalah pencemar yang sering terjadi dengan probabilitas $\geq$ $80 \%$ dengan parameter pada umumnya meliputi BOD, COD, TSS, Total N. Namun data kualitas air 
Sungai Cikapundung tidak mencukupi untuk mendapat total $\mathrm{n}$ karena keterbatasan data, sehingga digunakan parameter ammonia dan nitrit yang mewakili kandungan nitrogen pada Sungai Cikapundung. Gambar 2 menyajikan beban pencemar BOD dan COD Sungai Cikapundung pada tahun 2014-2016.

Beban pencemar BOD dan COD air sungai menunjukan banyaknya pencemaran organik yang ada di dalam air. Pencemaran BOD dan COD bersumber dari limbah rumah tangga. BOD secara umum banyak dipakai untuk menentukan tingkat pencemaran air buangan [3] Semakin besar nilai BOD atau COD, maka semakin tinggi pencemaran suatu perairan.

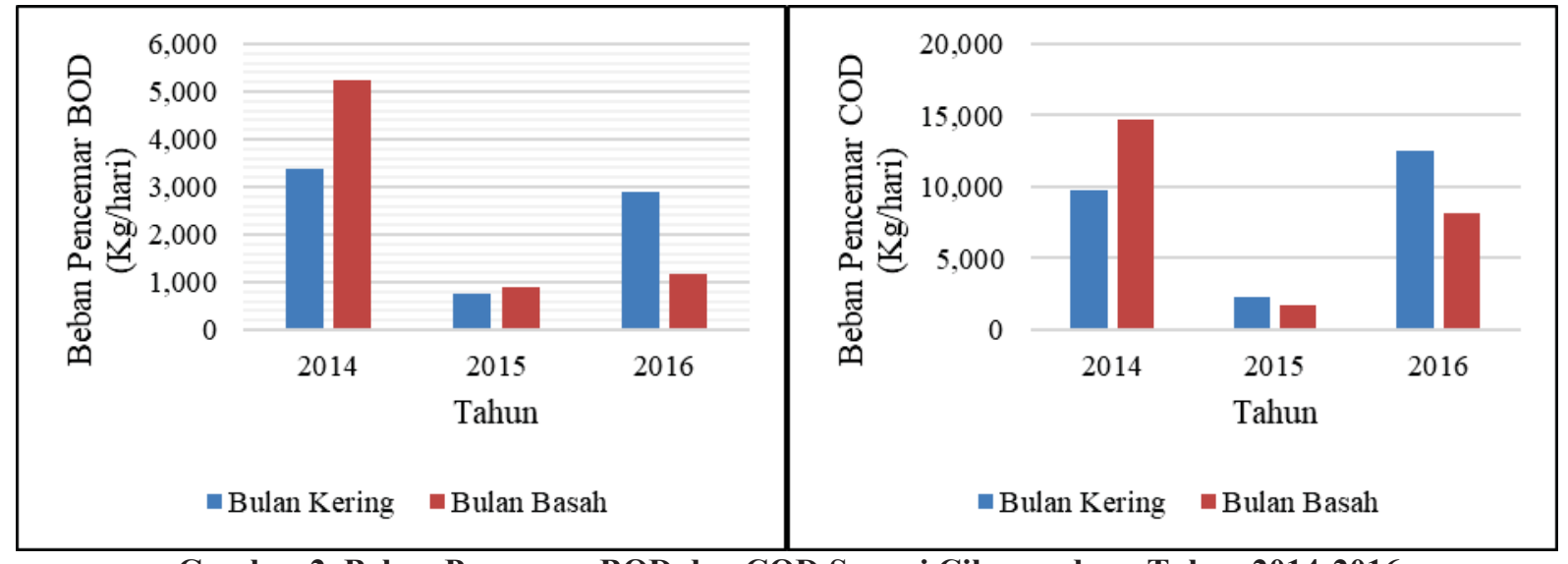

Gambar 2. Beban Pencemar BOD dan COD Sungai Cikapundung Tahun 2014-2016

Sungai Cikapundung dapat memberikan masukan organik tinggi karena adanya aktivitas dari pemukiman disekitar Sungai Cikapundung, tumpukan sampah yang berada pada Sungai Cikapundung juga menyumbang pencemaran organik pada sungai.

Gambar 2 menyajikan beban pencemaran BOD dan COD berfluktuatif setiap tahunnya, beban Pencemar BOD dan COD lebih besar di bulan kering dibandingkan bulan basah lebih kecil, hal ini dapat disebabkan terjadinya pengenceran konsentrasi organik ketika hujan. Menurut Slamet [1], air yang bukan berasal dari air lmbah dapat mengencerkan bahan organik. Adanya tambahan debit air dari berbagai sumber seperti mata air dan anak sungai bisa mengencerkan limbah organik, aliran air yang deras seperti aliran turbulen dan air yang jatuh mengalir dari tempat yang lebih tinggi, menyebabkan bahan organik hancur.

Zat tersuspensi yang ada dalam air terdiri dari berbagai jenis senyawa seperti selulosa, lemak, protein yang melayang-layang dalam air, atau dapat juga berupa mikroorganisme seperti bakteri, algae, dan sebagainya. Bahan-bahan organik ini selain berasal dari sumber-sumber alamiah juga berasal dari kegiatan manusia khususnya kegiatan rumah tangga, selain itu buangan yang berasal dari sektor pertanian, perternakan dan industri mengeluarkan bahan organik [4]. Maka dengan itu peningkatan beban pencemar TSS pada tahun 2016 di bulan basah dan bulan kering menunjukan pertumbuhan populasi penduduk yang ditandai dengan semakin banyaknya pembangunan rumah tinggal, tidak diiringi dengan peningkatan infrastruktur sanitasi. 


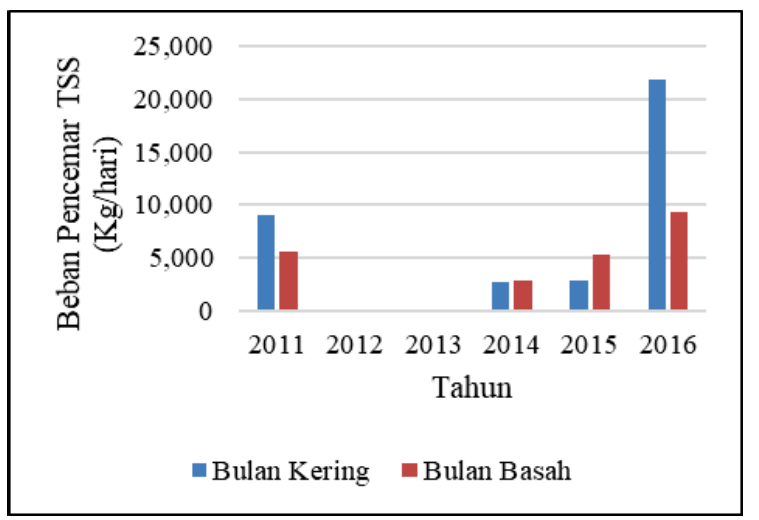

Gambar 3. Beban Pencemar TSS Sungai Cikapundung Tahun 2014-2016

Besarnya beban pencemar TSS di tahun 2016 pada bulan kering dapat di sebabkan pada saat pengambilan sampel air, sedimen yang berada pada perairan ikut terambil dan menyebakan besarnya konsentrasi TSS, peningkatan TSS ini dapat dipengaruh oleh pertumbuhan jumlah penduduk DAS Cikapundung. menurut [5] Air sungai dengan kosentrasi TSS yang tinggi dapat menyebabkan pendangkalan sungai serta menghambat penetrasi sinar matahari kedalam air dan menghambat fotosintesis tumbuhan dalam air.

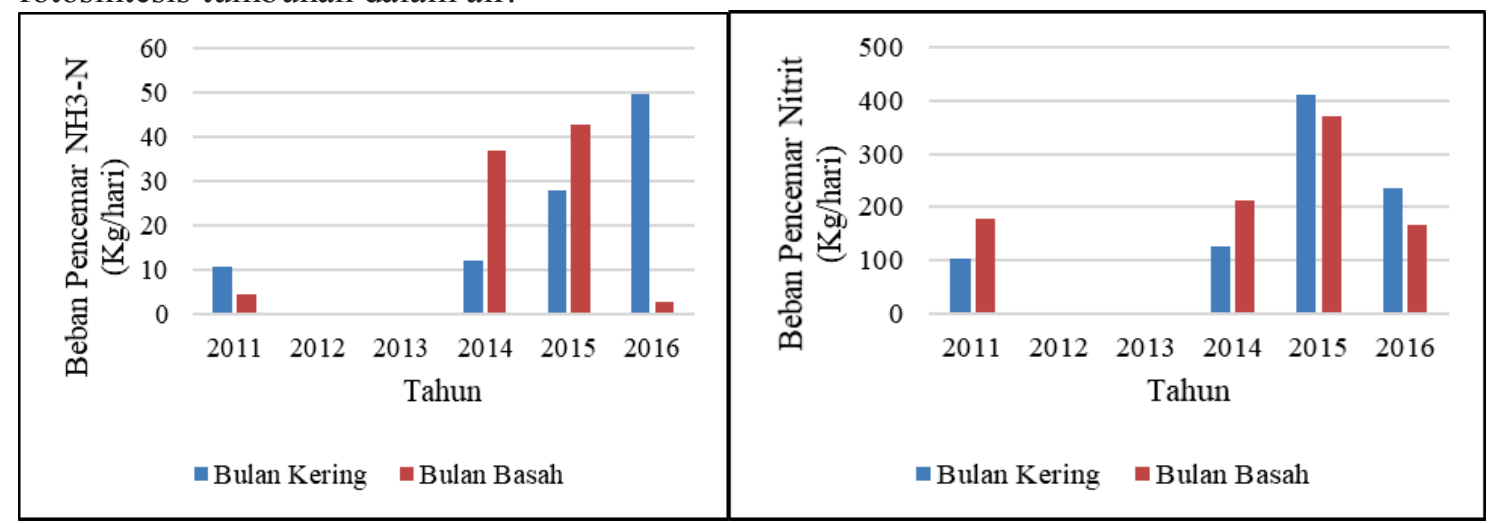

Gambar 4. Beban Pencemar $\mathrm{NH}_{3}-\mathrm{N}$ dan Nitrit Sungai Cikapundung Tahun 2014-2016

Nilai beban pencemaran $\mathrm{NH}_{3}-\mathrm{N}$ (Amonia) pada Gambar 4 rata-rata mengalami peningkatan setiap tahunnya pada bulan basah dan bulan kering, peningkatan nilai beban pencemar ammonia diindikasi berasal dari aktivitas MCK kegiatan rumah tangga yang mengeluarkan protein yang dapat terkandung didalam urin manusian. Menurut Sastrawijaya [6], menyatakan bahwa adanya amonia dan nitrit merupakan indikator masuknya buangan permukiman. Amonia dalam air permukaan berasal dari buangan permukiman penduduk, amonia berasal dari pembusukan protein tanaman/hewan dan kotoran.

Nitrit merupakan bentuk peralihan diantara ammonia dan nitrat, nitrit bersifat tidak stabil dengan keberadaan oksigen. Keberadaan nitrit menggambarkan berlangsungnya proses biologis perombakan bahan organik yang memiliki kadar oksigen terlarut rendah [4] maka dengan itu Meningkatnya beban pencemar nitrit pada Gambar 4 di tahun 2015 mengindikasi rendahnya kandungan oksigen pada perairan untuk mengoksidasi nitrit. Sungai Cikapundung yang melewati pemukiman padat berpengaruh terhadap tingginya beban pencemar nitrir pada sungai, Beban pecemaran nitrit disebabkan buangan rumah tangga yang menghasilkan bahan organik dari aktivitas MCK

\subsection{Perhitungan Potensi Beban Pencemar Domestik}

DAS Cikapundung yang memiliki 22 kecamatan terdiri dari 1 Kecamatan berada di Kabupaten Bandung Barat yaitu Kecamatan Lembang; 16 Kecamatan yang berada di Kota Bandung, yakni Kecamatan Astana Anyar, Bandung Kidul, Bandung Wetan, Batununggal, Cibeunying Kaler, Cibeunying Kidul, Cicendo, Cidadap, Coblong, Kiaracondong, Lengkong, Margacinta, Regol, 
Sukajadi, Sukasari, Sumur Bandung; dan 5 Kecamatan yang berada di Kabupaten Bandung adalah Kecamatan Baleendah, Bojongsoang, Cilengkrang, Cimenyan, Dayeuhkolot.

Berdasarkan hasil perhitungan, didapatkan jumlah penduduk yang masuk dalam DAS Cikapundung tertinggi pada Kecamatan Coblong sebesar 80.079 jiwa. Tingginya jumlah penduduk yang masuk dalam DAS dapat mencemari Sungai Cikapundung. Menurut Bahrein [7] 80\% pencemaran yang terjadi di Sungai Cikapundung disebabkan oleh limbah domestik, dan sisanya adalah limbah industri yang membuang bahan-bahan berbahaya dan beracun, seperti logam berat, ke aliran sungai

Beban pencemaran dari sektor domestik bersumber dari kegiatan manusia, seperti limbah black water (kotoran manusia) dan limbah grey water (limbah cair bekas mandi, cuci dan dapur). Faktor yang mempengaruhi kontribusi beban pencemaran dari kegiatan domestik meliputi jumlah penduduk serta jarak antara pemukiman penduduk dengan Sungai Cikapundung. Dalam hal ini diasumsikan semakin dekat jarak antara pemukiman dengan sungai, semakin besar kontribusinya terhadap beban pencemaran. Penduduk yang tinggal di sepanjang bantaran DAS sebagian besar membuang limbahnya ke sungai secara langsung.

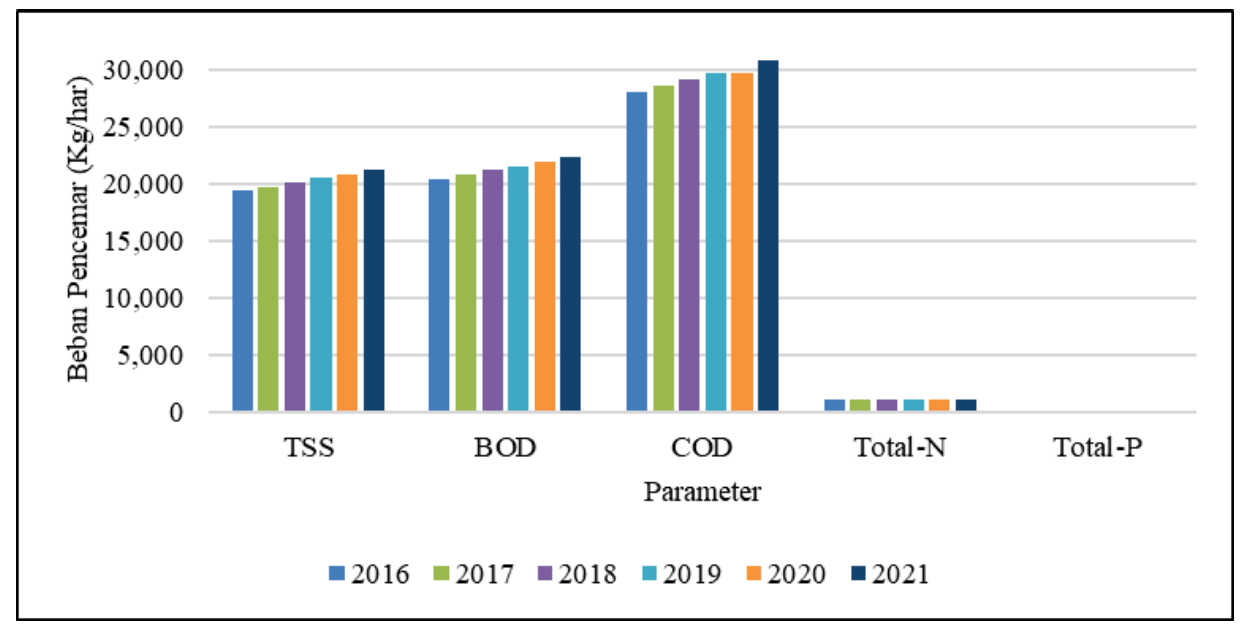

Gambar 5. Beban Pencemar Sektor Domestik DAS Cikapundung Tahun 2016-2021

Gambar 5 menunjukan bahwa sektor domestik menyumbang beban pencemaran terbesar pada Sungai Cikapundung COD, BOD, dan TSS, namun beban pencemar yang terukur pada Sungai Cikapundung tidak hanya berasal dari sektor domestik dilihat dari penggunaan lahan DAS Cikapundung sektor pertanian, perternakan serta industri turut memberikan masukan pencemaran yang terakumulasi di sungai.

Gambar 6 menyajikan beban pencemar tinggi berada di Kecamatan yang memiliki cakupan luas lahan yang besar pada DAS Cikapundung seperti Kecamatan Lembang, Bandung Kidul, Bandung Wetan, Coblong, Batununggal, Regol, Lengkong, Sumur Bandung dan Dayeuhkolot. Pengaruh cakupan luas lahan Kecamatan pada DAS Cikapundung terhadap beban pencemar domestik adalah semakin besar cakupan luas lahan pada DAS, maka jumlah penduduk yang masuk akan semakin besar, karena perhitungan potensi beban pencemar domestik ini didasarkan atas jumlah jiwa pada DAS.

Beban pencemaran BOD Sungai Cikapundung akan dibandingkan dengan beban pencemaran BOD sektor domestik pada daerah yang sama, yaitu di Kelurahan Pasirluyu Kecamatan Regol karena titik sampling pengukuran kualitas air yang dilakukan oleh Balai Besar Wilayah Sungai Citarum (BBWS Citarum) dilakukan pada daerah tersebut. Potensi beban pencemar BOD Kecamatan Regol sebesar $2.102,66 \mathrm{~kg} /$ hari dan beban pencemar BOD yang terukur adalah $2.622,14 \mathrm{~kg} /$ hari, maka Kecamatan Regol menyumbang $80,19 \%$ pencemaran yang disebabkan oleh BOD yang berasal dari limbah domestik Kecamatan Regol. Sedangkan pada potensi beban pencemaran COD sebesar 3.182,76 $\mathrm{kg} /$ hari dengan beban pencemar terukur COD $11.880,72 \mathrm{~kg} /$ hari, maka $26,78 \%$ beban pencemaran 
COD berasal dari limbah domestik Kecamatan Regol dan di duga adanya sumbangan pencemaran lainnya selain domestik yang masuk ke dalam sungai dan mempengaruhi beban pencemaran COD.

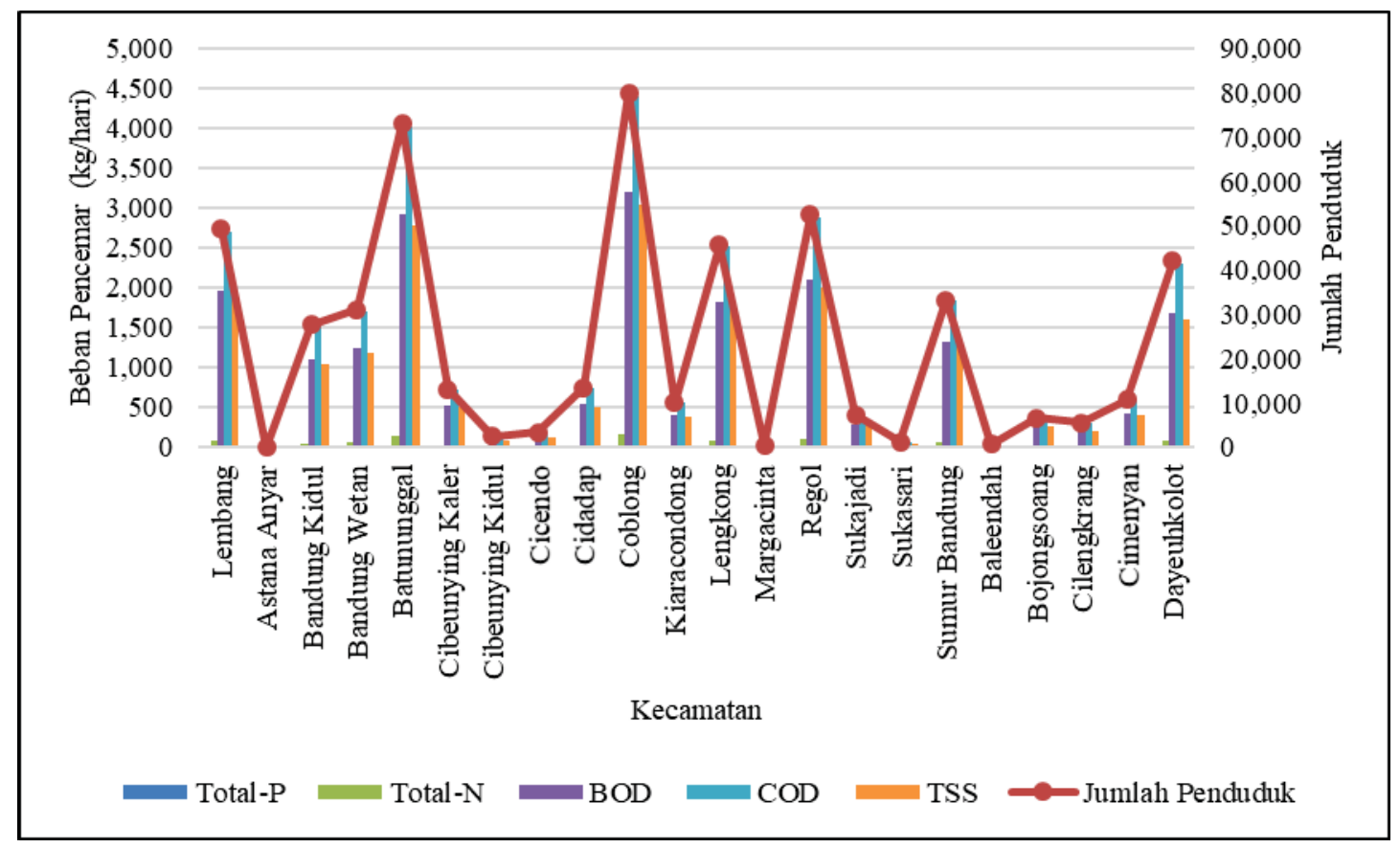

Gambar 6. Beban Pencemaran Domestik pada DAS Cikapundung

Parameter total-N dan total-P yang diperhitungkan tidak dapat dibandingkan dengan beban pencemar, karena tidak ada data pengukuran nitrogen organik, dan nitrat yang nantinya bersama dengan konsentrasi ammonia dan nitrit dapat meresepresentatifkan total-N, serta tidak ada pengukuran total-P. Potensi beban pencemar total-N dan total $\mathrm{P}$ pada setiap kecamatan tidak melebihi daya tampung Sungai Cikapundung, perhitungan total- $\mathrm{N}$ dan total-P pada potensi beban pencemaran limbah domestik di karenakan limbah domestik menurut sugiharto, dalam saraswati, [8] menyatakan bahwa limbah domestik mengandung $40-60 \%$ protein, protein dalam limbah domestik pada perairan merupakan salah satu sumber kandungan nitrogen organik selain urea, kemudian akan dikonversi menjadi ammonia dan akan berubah menjadi nitrit dan nitrat pada tahapan oksidasi bila memiliki kandungan oksigen yang cukup, parameter-parameter tersebut merupakan kandungan dari nitrogen total, total $\mathrm{p}$ pada limbah domestik dapat berasal dari detergen yang sering digunakan sebagai bahan pencuci baju.

Buangan organik banyak mengandung fosfat yang berasal dari bubuk detergen (air cucian), selain itu urine manusia juga banyak mengandung fofor sebagai hasil dari metabolisme pemecahan senyawa protein yang masuk, total-P tidak bersifat toksik bagi manusia, hewan dan ikan. Keberadaan total-P dalam jumlah besar dapat menyebabkan ledakan pertumbuhan algae di perairan (booming algae) sehingga kadar oksigen terlarut dalam perairan akan berkurang dan menyebabkan kematian pada ikanikan, maka agar hal itu tidak terjadi diperlukan pengendalian agar kandungan total-P dalam Sungai Cikapundung tidak menyebabkan kerugian bagi manusia, hewan, dan ikan.

Tahun 2016 sesuai Gambar 7 potensi beban pencemar tanpa pengendalian dan dengan pengendalian memiliki total beban pencemar yang sama besar pada setiap parameter, karena tahun 2016 merupakan data eksisting dimana pada tahun tersebut sudah adanya pengendalian berupa IPAL pada setiap daerah kota/kabupaten, namun cakupan pelayanan IPAL yang melayani warga DAS Cikapundung masih sangat kecil pada beberapa daerah, maksud dari tanpa pengendalian adalah tidak meningkatnya cakupan pelayanan IPAL pada masing-masing daerah sedangkan dengan adanya pengendalian adalah diasumsikan tercapainya target peningkatan cakupan pelayanan IPAL yang disusun oleh pemerintah daerah masing-masing pada setiap tahunnya dengan target peningkatan pengendalian dilaksanakan 
pada tahun 2017, hal ini yang mendasari beban pencemar tanpa pengendalian dan dengan pengendalian memiliki nilai yang sama di tahun 2016.

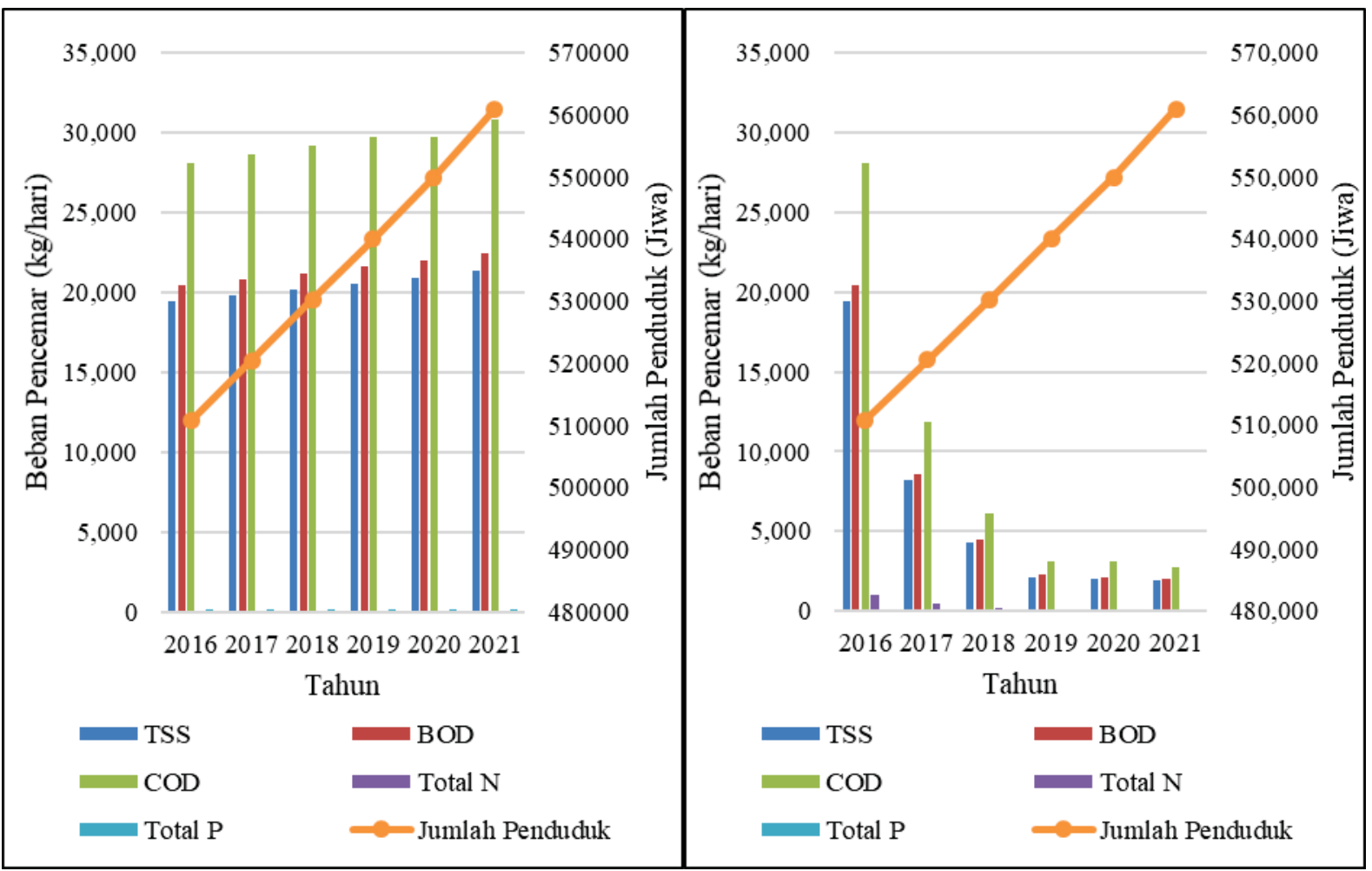

(a) (b)

Gambar 7. Potensi Pencemaran Limbah Domestik DAS Cikapundung Tahun 2016-2021 (a) Tanpa Pengendalian, (b) Dengan Pengendalian

Adanya pengendalian akan mempertimbangkan pola sanitasi Kabupaten Bandung telah menargetkan untuk sistem off-site kenaikan 0,45\% dari tahun eksisting dan 3,33\% untuk sistem on-site, Sedangkan Kota Bandung dan Kabupaten Bandung Barat menargetkan pada tahun 2019 cakupan sanitasi 100\% ( $85 \%$ off-site, $15 \%$ on-site). Dari perhitungan tersebut dapatkan besaran proyeksi potensi beban pencemar total pada sungai Cikapundung yang disajikan pada Gambar 7

Peningkatan jumlah penduduk akan akan meningkatkan potensi beban pencemaran domestik bila tidak ada pengendalian seperti pada Gambar 7, meningkatnya potensi beban pencemaran domestik akan mencemarkan perairan bila tidak adanya tindakan pengendalian akibat terlampaui daya tampung sungai oleh beban pencemaran domestik yang masuk. Adanya tindakan pengendalian pada Gambar 7 dapat meminimasi potensi beban pencemar yang berasal dari limbah domestik.

\section{KESIMPULAN}

Kualitas Sungai Cikapundung pada tahun 2016 tergolong cemar sedang pada bulan kering dan cemar ringan pada bulan basah, di tahun 2015 indeks pencemar Sungai Cikapundung mencapai 23,58 di bulan kering dengan kategori cemar berat, hal ini menunjukan bahwa banyaknya pencemar yang masuk khususnya dari kotoran manusia yang berasal dari aktivitias mandi, cuci, kakus (MCK) penduduk, dan sektor lain seperti pertanian, perternakan, dan industri yang melebihi daya tampung dan menyebabkan air menjadi tercemar.

Beban pencemaran sektor domestik yang besar berada di Kecamatan Lembang, Bandung Kidul, Bandung Wetan, Coblong, Batununggal, Regol, Lengkong, Sumur Bandung dan Dayeuhkolot, karena besar jumlah penduduk pada setiap Kecamatan tersebut. 
Beban pencemaran limbah domestik ini dipengaruhi oleh jumlah penduduk, meningkatnya jumlah penduduk suatu DAS akan meningkatkan beban pencemaran domestik. dengan adanya target peningkatan cakupan pelayan Sistem Pengolahan Air Limbah (SPAL) baik on-site maupun off-site pada masing-masing daerah dapat meminimasi pencemaran yang berasal dari sektor domestik.

\section{DAFTAR PUSTAKA}

[1] Selamet, Sofyan, Iendra. 2004. 'Pengaruh Tata Guna Lahan Terhadap Terhadap Kualitas dan Kuantitas Air Sungai Cikapundung'. Universitas Dipenogoro

[2] Iskandar. (2007). Panduan Pelatihan Pengelolaan Kualitas Air

[3] Manik, K. E. S, 2016, Pengelolaan Lingkungan Hidup, Djambatan, Jakarta

[4] Effendi, Hefni. 2003, Telaah Kualitas Air, Bagi Pengelolaan Sumber Daya dan Lingkungan Perairan (Kanisius: Yogyakarta)

[5] Nurmalita, Maudilia, \& Syukri, M. (2014). Analisa Kekeruhan dan Kandungan Sedimen dan Kaitannya dengan Kondisi DAS Sungau Krueng Aceh

[6] Sastrawijaya, T. (2000). Pencemaran Air. Bandung: Rineka Cipta.

[7] Bahrein, S. (2012). Pengembangan Daerah Aliran Sungai (DAS) Cikapundung: Diagnostik Wilayah .

[8] Saraswati, P. S., Sunyoto, Kironoto, B. A., \& Hadisusanto, S. (2013). Kajian Bentuk dan Sensitivitas Rumus Indeks PI, Storet, CCME Untuk Penentuan Status Mutu Perairan Sungai Tropis di Indonesia. Manusia dan Lingkungan, 21, 129-142. 